že je osobnost hraběte Bethlena stále aktuálním tématem, dokládá také kniha Bryana Cartledge z roku 2009. ${ }^{7}$ Přesto se domnívám, že je monografie Andreje Tótha ojedinělá - svým originálním přístupem, kontextualizací i velmi poctivou prací s archivními materiály. Oceňuji srozumitelnost výkladu i zasazení tématu do širších souvislostí střední Evropy. Obojí přispívá jak k osvětlení problematiky politického systému Istvána Bethlena v meziválečném Mad'arsku, tak k pochopení složitého, ale důležitého období československo-madiarských vztahů.

Tereza Auzká

doi: $10.14712 / 23363231.2017 .5$

\title{
Tobias Huff, Natur und Industrie im Sozialismus. Eine Umweltgeschichte der DDR.
} Göttingen: Vandenhoeck \& Ruprecht, 2015, 470 s. ISBN 978-3-525-31717-4

V druhé polovině roku 2015 se na německý knižní trh dostala nová publikace Tobiase Huffa Natur und Industrie im Sozialismus. Eine Umweltgeschichte der DDR (Př́roda a průmysl za socialismu. Dějiny životního prostředí v NDR), jejímž tématem je historie ochrany životního prostředí v bývalé Německé demokratické republice v letech 1949-1989. Přestože jméno autora ani samotný obor environmentální historie nejsou české historické obci příliš známé, zaslouží si recenzovaná publikace pozornost. Huffova kniha totiž představuje zásadní příspěvek do diskuze nejen o samotných environmentálních dějinách NDR a později znovusjednoceného Německa, ale také o tom, jak se východoněmecké politické elity a společnost stavěly ke znečištování prostředí, zda je tyto problémy zajímaly, nebo jestli je raději záměrně přehlížely.

Je to již deset let, co byla vydána poslední ucelená monografie zabývající se environmentálními dějinami Německa, a to z pera německého historika Jense Iva Engelse. ${ }^{1}$ V recenzované publikaci přichází Huff s podobným tématem, ale na rozdíl od svých předchůdců se věnuje historii ochrany životního prostředí v plánované ekonomice NDR, která - podobně jako bývalé Československo - neblaze proslula fatálním poškozováním lesů a celkovým ignorováním životního prostředí.

Autor knihy působí jako odborný asistent na katedře moderních dějin na univerzitě v Mohuči. Recenzovaná monografie je výsledkem jeho tř́letého grantu, který mu

Gergely, A keresztényszocializmus Magyarországon: 1903-1923 (Budapest: Akadémiai Kiadó, 1977). Z anglofonních autorů srov. např. Thomas Lorman, Counter-Revolutionary Hungary: 1920-1925: István Bethlen and the Politics of Consolidation (Boulder, CO: East European Monographs, 2006); William M. Batkay, Authoritarian Politics in a Transitional State: Istvan Bethlen and the Unified Party in Hungary 1919-1926 (New York: Columbia University Press, 1982).

7 Bryan Cartledge, Mihály Károlyi and István Bethlen. Hungary (London: Haus Publishing, 2009).

1 Jens Ivo Engels, Naturpolitik in der Bundesrepublik: Ideenwelt und politische Verhaltensstile in Naturschutz und Umweltbewegung 1950-1980 (Paderborn: Ferdinand Schöningh, 2006). 
poskytla Deutsche Forschungsgemeinschaft a na němž Huff pracoval v rámci své disertace na Albert-Ludwigs-Universität ve Freiburgu. Disertaci obhájil v roce 2012. Kromě environmentálních dějin a dějin změn klimatu se Huff zaměřuje i na hospodářské dějiny, sociální dějiny Evropy a dějiny NDR.

Recenzovaná monografie má kromě úvodní metodologické kapitoly další čtyři kapitoly, jejichž názvy odpovídají jednotlivým analyzovaným dekádám od počátku padesátých let do konce osmdesátých let 20. století. Každá z hlavních čtyř kapitol by si zasloužila samostatnou publikaci, už jen s ohledem na velmi rozdílný vývoj v každém desetiletí, který se výrazně odrazil i v prŕistupu k životnímu prostředí. To však neznamená, že by se Huff věnoval některému období více než jinému nebo že by se nechal zavalit množstvím archivních zdrojů. Ba naopak, každá kapitola je pro lepší přehlednost ukončena dílčími závěry a shrnutím nejdůležitějších informací. Na konci knihy je pak jako součást hlavního závěru uveden také jakýsi souhrn hlavních otázek a odpovědí na ně, následuje rozsáhlý seznam použitých pramenů a literatury. Z pohledu čtenáře je studie jasně strukturována a díky dílčím závěrům a celkovému závěrečnému shrnutí i čtivá. Celkových 470 stran nabízí také fotografie $\mathrm{z}$ archivů (zajímavé jsou snímky znečištěné přírody $\mathrm{v}$ Krušných horách, např. s. 127 a 129), grafy, mapy, úryvky z osobní korespondence či záznamy autorových rozhovorů s bývalými politiky a jinými významnými osobami.

Přestože podtitul knihy zní Dějiny životního prostředí v NDR, přesahuje zpracovávaná tematika často hranice východního Německa. Životní prostředí je totiž samo o sobě tématem mezinárodním, které bylo od sedmdesátých let řešeno na základě mezinárodních smluv a úmluv, a to i v zemích bývalého sovětského bloku. V souvislosti s ekologickou politikou proto Huff uvádí četné příklady vlivu SRN a Československa, v menší míre pak USA, Velké Británie či Sovětského svazu.

Hlavní výzkumná otázka, kterou si Huff klade, zní „proč znečištování a poškozování životního prostředí vyvolalo $\mathrm{v}$ obou německých státech ve stejném časovém období tak diametrálně odlišné politické a sociální ohlasy?“ (s. 18). První odpověd' směřuje logicky k rozdílu mezi tržním a socialistickým chápáním přírody, ovšem autor připisuje velký vliv také společenskému prostředí, vývoji uvnitř SED a vztahům NDR s ostatními východními i západními státy. Dále si Huff klade za cíl identifikovat aktéry, kteří vytvářeli východoněmeckou ekologickou politiku - tedy politiky, nevládní organizace či další významné jednotlivce.

Metodologicky je monografie pojata jako příspěvek k environmentálním dějinám, které jsou známé svou interdisciplinaritou. Proto je třeba autorovi vytknout, že tuto disciplínu podrobněji nepředstavuje a nesnaží se ji odlišit od jiných směrů historiografie hlavně od sociálních, hospodářských a nových politických dějin. To je ovšem problém většiny současných prací. ${ }^{2}$ Nejčastěji bývají environmentální dějiny řazeny právě mezi

$2 \mathrm{~V}$ tomto kontextu je zajímavé, že v českém prostředí sice téměř žádné studie na témata $\mathrm{z}$ environmentálních dějin nevycházejí, ale jejich metodologie byla poměrně dobře popsána Leošem Jelečkem z Přírodovědné fakulty UK. Srov. Leoš Jeleček, „Environmentální dějiny: Jejich vznik, 
sociální dějiny, ty se však zaměřují na studium lidské společnosti. Mají-li být environmentální dějiny někam zařazeny, pak podle mého názoru jedině mezi nové politické dějiny se silným vlivem dějin mezinárodních vztahů a hospodářských dějin, což mimochodem dokazují různé studie o vlivu ekologických hnutí na tvorbu politiky nebo o vzniku Strany zelených. ${ }^{3}$

Kniha je výsledkem rozsáhlého archivního výzkumu, který tvoří jednu z hlavních přidaných hodnot této knihy. Přesto se právě množství archivních zdrojů (jejich výčet zabírá celkem 33 stran) a nekonzistentnost v jejich výběru staly předmětem výtek, které vznesl mnichovský historik Arnošt Štanzel ve své recenzi na Huffovu monografii. ${ }^{4}$ Podle Štanzela vedl obrovský počet archivních zdrojů k zahlcení čtenáře, a to hlavně v poslední kapitole věnované nevládním organizacím. Na jednotlivých kapitolách je sice už podle počtu stran vidět, že k padesátým letům byl počet pramenů omezený, zatímco k osmdesátým letům byl velmi rozsáhlý, i tak se ale domnívám, že Huff zvolil vhodný výběr, který dobře popisuje jednotlivé aktéry ekologické politiky NDR. Ze zpracovaných zdrojů autor úmyslně vyloučil oficiální média jako noviny, časopisy, rozhlasové a televizní pořady, a to kvůli záměrně zkresleným informacím (s. 33).

Hlavním zdrojem pro analýzu padesátých let se stal archiv Technické univerzity v Dráždlanech, zejména dokumenty Lesnické fakulty v Tharandtu, na které působili první ekologičtí výzkumníci NDR. S koncem šedesátých let 20. století se tematika ochrany lesů přesunula $\mathrm{z}$ akademického prostředí na státní úroveň, kde však figurovala spíše jako prostředek propagandy. Prameny $\mathrm{k}$ tomuto období byly rešeršovány ve vybraných fondech Ministerstva zemědělství a lesnictví, Ministerstva vědy a techniky, Ministerstva životního prostředí a vodního hospodářství, Ministerstva státní bezpečnosti, Státní plánovací komise a Akademie zemědělských věd ve Spolkovém archivu v Berlíně - Lichterfelde. Do archivní rešerše zahrnul Huff také specializovaná periodika, konkrétně Sozialistische Forstwirtschaft, Archiv für Forstwesen a Wissenschaftliche Zeitschrift der Technischen Universität Dresden. Již takto velmi rozsáhlý archivní výzkum doplnil autor o rozhovory s pamětníky, které vedl v letech 2010 a 2011. Sám Huff označuje za nejcennější respondenty pamětníky sociálních hnutí z osmdesátých let, a to Hanse-Petera Gensichena a Gerharda Pfeiffera, autory první samizdatové a zakázané literatury o vymírání lesů z roku 1985, a Hanse Reichelta, bývalého ministra zemědělství a lesnictví (1953-1954 a 1955-1963), později ministra životního prostředí a vodního hospodářství (1971-1990).

konceptualizace a institucionalizace (USA, Evropa a svět)“, Annales historici Presovienses 9 (2009): 247-74; Leoš Jeleček, „Environmentalizace vědy, geografie a historické geografie: Environmentální dějiny a výzkum land use Česka v 19. a 20. století“, Klaudyán 4, č. 1 (2007): 20-28.

3 Srov. např. Jan-Henrik Meyer, „,Where do we go from Wyhl?‘ Transnational Anti-Nuclear Protest in the 1970s", Historical Social Research 39, č. 1 (2014): 212-35; Silke Mende, Nicht rechts, nicht links, sondern vorn: Eine Geschichte der Gründungsgrünen (München: Oldenbourg, 2011).

4 Srov. Arnošt Štanzel, recenze knihy Natur und Industrie im Sozialismus. Eine Umweltgeschichte der DDR, Tobias Huff, H-Soz-Kult (19. záŕí 2015), www.hsozkult.de/publicationreview/id/ rezbuecher-24433. 
Co se týče knižních zdrojů, odkazuje Huff na nejznáměǰś německé environmentální historiky, kterými jsou zejména Karl Ditt, již zmiňovaný Jens Ivo Engels či Kai F. Hünemörder. ${ }^{5}$ Vedle nich je seznam literatury bohatý také na publikace k politickým a hospodářský tématům NDR či na samizdatovou literaturu ekologických hnutí z osmdesátých let.

Samotná analýza jednotlivých dekád (1. až 4. kapitola) nabízí čtenáři ucelený pohled na dějiny životního prostředí NDR. Jak autor uvádí, jejich počátek je spojován se změnou postoje člověka k př́rodě, která nastala na konci šedesátých let na Západě (s. 13). ${ }^{6}$ Přesto se již v padesátých letech (1. kapitola) objevily první socialistické pokusy o zmírnění dopadů těžkého průmyslu na př́rodu. Výzkumným centrem NDR se stala Lesnická fakulta v Tharandtu při Technické univerzitě v Dráždanech. Zde vznikl vůbec první výzkumný tým pod vedením Reinholda Lingnera (mimo jiné také dvorního zahradního a krajinného architekta SED), který zkoumal vliv koư̌e na lidské zdraví a stav př́rody. Později převzal výzkum jeho žák Erich Zieger. Huff oba označuje za „pionýry životního prostředí“ (s. 37), ačkoliv jejich výzkum nepovažuje za nijak inovativní ani komplexní - problémy byly zkoumány složkově, tj. odděleně, a ne jako celek. Výsledkem tohoto výzkumu bylo potvrzení teorie, že prach a emise škodlivých plynů do ovzduší poškozují lesy a škodí lidskému zdraví. Tyto výsledky však nebyly téměř publikovány - nejenže je nebylo kde zveřejnit, ale také o ně nebyl zájem. $V$ padesátých letech tak byla ochrana životního prostředí výhradně tématem vědeckým, nikoli politickým a již vůbec ne společenským.

Další kapitola se zabývá revolučními šedesátými lety. I když se nejvýznamnější změny odehrály hlavně na Západě, východoněmecký režim si je nemohl dovolit zcela ignorovat. Na nově vzniklou ekologickou politiku západních sousedů (nejen SRN, ale také Velké Británie, Francie a hlavně USA) musela SED reagovat. Na konci šedesátých let tak začalo období prvních kompromisů mezi pětiletými plány a ochranou životního prostředí, které ve skutečnosti nikdy žádnými kompromisy nebyly, i když tak měly navenek vypadat: výrobní činnost a splnění pětiletek měly vždy přednost. Přesto, jak ukazuje 3. kapitola, byla od sedmdesátých let zaváděna četná ekologická opatření, která měla doma i v zahraničí vyvolávat dojem, že jsou pokrokovější a mnohem efektivnější

5 Srov. např. Karl Ditt, „Die Anfänge der Umweltpolitik in der Bundesrepublik Deutschland während der 1960er Jahre und frühen 1970er Jahre", in Demokratisierung und gesellschaftlicher Aufbruch: Die sechziger Jahre als Wendezeit der Bundesrepublik, ed. Matthias Frese a Julia Paulus (Paderborn: Ferdinand Schöningh, 2003): 305-47; Engels, Naturpolitik in der Bundesrepublik; Kai F. Hünemörder, „Vom Expertennetzwerk zur Umweltpolitik: Frühe Umweltkonferenzen und die Ausweitung der öffentlichen Aufmerksamkeit für Umweltfragen in Europa (1959-1972)“, Archiv für Sozialgeschichte 43 (2003): 275-96; Kai F. Hünemörder, Die Frühgeschichte der globalen Umweltkrise und die Formierung der deutschen Umweltpolitik (1950-1973) (München: Franz Steiner, 2004).

6 Zde Huff odkazuje na Ronalda Ingleharta, sociologa sedmdesátých a osmdesátých let, který psal o změně společenských hodnot v souvislosti s proměnou konzumní společnosti a růstem blahobytu. Srov. Ronald Inglehart, „The Silent Revolution in Europe: Intergenerational Change in Post-Industrial Societies“, The American Political Science Review 65, č. 4 (1971): 991-1017; Ronald Inglehart, Culture Shift in Advanced Industrial Society (New Jersey: Princeton University Press, 1990); Ronald Inglehart, Modernization and Postmodernization: Cultural, Economic, and Political Change in 43 Societies (Princeton: Princeton University Press, 1997). 
než kroky západoněmecké vlády. Př́ikladem hodným obdivu měl být hlavně vznik Ministerstva životního prostředí a vodního hospodářství, které bylo v NDR založeno již v roce 1971 v čele s ministrem Hansem Reicheltem, a to jako vůbec první ministerstvo svého druhu v celé Evropě (s. 35). ${ }^{7}$ Huff dodává, že založení východoněmeckého Ministerstva životního prostředí a vodního hospodářství mělo být hlavně symbolem socialistické propagandy před stockholmskou konferencí OSN v roce 1972 (s. 166-67). ${ }^{8}$

Poslední kapitola analyzuje osmdesátá léta, tedy dobu, kdy nastala konečná fáze degradace lesů $\mathrm{v}$ důsledku ignorování ochrany přírody během předchozích čtyřiceti let. Zároveň to ale byla také dekáda, v níž vznikla řada východoněmeckých ekologických hnutí a nevládních organizací, které se téměř s dvacetiletým zpožděním začaly zajímat o životní prostředí. Zejména situace v Krušných horách okolo nejvyšších vrcholů, tj. Fichtelbergu a Klínovce, se v osmdesátých letech zhoršila natolik, že již nebylo možné mrtvé lesy přehližzet. Zajímavé je, že to byl právě východoněmecký režim, který inicioval mezinárodní setkání s tehdejším Československem a chtěl docílit dohody o změně přístupu k pohraničním lesům. Tato jednání však skončila bez výsledku a Huff na základě archivních materiálů ukazuje, že to bylo vinou hlavně československých zástupců (s. 225-34).

Jak moc situace v Krušných horách eskalovala, dokazují i četné dopisy nalezené v archivu Ministerstva životního prostředí a vodního hospodářství NDR. Většinou to byly dopisy obyvatel poškozené oblasti nebo turistů, například následující: „Během dovolené v červenci tohoto roku [1980 - pozn. aut.] jsme pobývali v Krušných horách v Oberwiesenthalu. Při výšlapu na Fichtelberg se mi naskytl smutný pohled. Všechny stromy na hřebenech hor, jedno zda listnaté či jehličnaté, jsou mrtvé. [...] To nemohla způsobit tuhá zima. Místní obyvatelé mi vyprávěli, že lesy v této části hor umírají již několik let. Jak je možné, že situace došla tak daleko, když se o ochraně životního prostředí v NDR hovoří tak často?““ (s. 308).

Na stále se zhoršující situaci a nečinnost režimu reagovala východoněmecká společnost zakládáním a podporou nevládních organizací. Těch rozhodně neexistovalo v NDR tolik jako v SRN, kde ekologická hnutí měla od druhé poloviny sedmdesátých let velmi silnou pozici, a dokonce iniciovala vznik „strany protestu“ - Strany zelených (Die Grünen). ${ }^{9}$ Vůbec první nevládní organizace byly náboženskými uskupeními, která kromě

7 Pro srovnání v SRN vzniklo samostatné ministerstvo životního prostř̌edí až v roce 1986 jako reakce na výbuch atomové elektrárny v ukrajinském Černobylu, od sedmdesátých let spadala problematika ochrany životního prostředí pod Spolkové ministerstvo vnitra v čele s Hansem-Dietrichem Genscherem jako vůbec prvním ministrem, který se problematikou ochrany životního prostředí musel zabývat. Srov. Bundesarchiv Koblenz, Ministerium des Innern, fond 106/25940.

8 Konference nazvaná „The United Nations Conference on the Human Environment“ byla vůbec největší konferencí do té doby a zdůrazňovala bezprostřední souvislost mezi lidmi (human) a stavem životního prostředí (environment). Vůbec poprvé se této konference zúčastnily státy z obou stran železné opony (včetně ČSSR).

9 Srov. Pavla Kačmárová, „Environmentální obrat společnosti sedmdesátých let 20. století a možnosti environmentální historie na př́kladu vzniku strany Zelených (Die Grünen) SRN“, in Nové př́stupy $k$ metodologii hospodáŕrkých a politických dějin, ed. Irena Kozmanová (Praha: Setoutbooks.cz, 2013): 108-26. 
mírových aktivit podporovala také ochranu životního prostředí. Vedoucí postavou se stal Hans-Peter Gensichen, mluvčí organizace Kirchliches Forschungsheim Wittenberg. Gensichen vydal společně s Gerhardem Pfeifferem první neoficiální publikaci o vymírání lesů v NDR nazvanou Wie man in den Wald rußt... (volně přeloženo „Jak se do lesa čoudí...").10 Později začaly vycházet samizdatové časopisy, knihy či básně s ekologickou tematikou, Huff zmiňuje např́íklad časopisy Umweltblätter, Streiflichter nebo Arche Info.

Huff se na závěr analýzy osmdesátých let věnuje nejdůležitější nevládní organizaci nazvané Společnost pro př́rodu a životní prostředí (Die Gesellschaft für Natur und Umwelt, GNU). Tato organizace, jako vůbec jediná povolená východoněmeckým režimem, byla založena v roce 1980 , a to z prostého důvodu - SED se správně domnívala, že pokud vznikne oficiální organizace zastřešující ekologickou tematiku, bude ji mít pod svou kontrolou, a že zároveň umlčí narůstající ekologické protesty, když bude prostřednictvím GNU organizovat různé ekologické dobrovolnické práce. GNU se zpočátku těšila obrovské popularitě, krátce po svém vzniku měla 40000 členů, kteří byli rozděleni do 1600 pracovních skupin na různé práce $\mathrm{v}$ přírodě a ve městech (s. 388). Přestože GNU vznikla na popud východoněmeckého režimu, oficiálně měla zůstat apolitická. Takto se také prezentovala, i když samožrejmě nikdy nevládním hnutím v pravém slova smyslu nebyla. V roce 1989 ukončila GNU svou činnost, někteří její členové pak založili první východoněmeckou Stranu zelených - Die Grüne Partei in der DDR, která se roku 1990 sloučila se západoněmeckou stranou Die Grünen. ${ }^{11}$

Souhrnně lze konstatovat, že recenzovaná monografie předkládá řadu otázek, které na základě rozsáhlé archivní rešerše přesvědčivě zodpovídá. Vybízí také $\mathrm{k}$ dalšímu studiu rozličných témat jak př́imo $\mathrm{v}$ rámci environmentálních dějin, tak $\mathrm{v}$ dalších oborech historiografie. Zároveň autor vyvrací často mytizované „pravdy“ o naprostém ignorování ochrany životního prostředí v komunistickém režimu a na několika příkladech dokazuje, že se východoněmecká společnost snažila přispět $\mathrm{k}$ tomu, aby se znečištování prírody zmenšovalo. $\mathrm{O}$ tzv. př́íkladech dobré praxe hlavně v SRN již bylo v historické literatuře řečeno mnoho, naopak historie socialistického pojetí ochrany životního prostředí je tématem novým a více jak 25 let po pádu socialismu stále téměř neprobádaným. ${ }^{12}$

Huff, který se v úvodu ptá na důvody rozdílného př́stupu obou německých států a společností k lesům, předkládá tyto odpovědi: Ekonomický i kulturní vývoj byl v obou státech od padesátých let tak rozdílný, že ve Spolkové republice umožnil vznik ekologických hnutí a Strany zelených, které i v současné době platí za vzor. V NDR se naopak

${ }^{10}$ Hans-Peter Gensichen a Gerd Pffeifer, Wie man in den Wald rußt (Wittenberg: [b.n.], 1985). Převzato z Huff, Natur und Industrie, 322.

${ }^{11}$ V SRN vznikla Strana zelených již v roce 1980. O tři roky později překročila poprvé hranici pěti procent voličských hlasů a dostala se do Spolkového sněmu.

$12 \mathrm{Z}$ aktuálních projektů srov. nap̌r. grant GA ČR „Stalinský plán přetvoření přírody v Československu, 1948-1964“, řešený v Ústavu pro soudobé dějiny AV ČR, či výzkumný projekt Martina Zückerta z Collegium Carolinum München nazvaný „Na okraj socialistické modernizace? Strukturální plánování, environmentální politika a změna krajiny v horských oblastech na Slovensku 1945-1970“. 
ochrana životního prostředí stala pouze nástrojem propagandy režimu SED, ve skutečnosti bylo stále rozhodující splnit výrobní plány pětiletek. Podle Huffa se západoněmecký a východoněmecký př́stup k životnímu prostředí začal diametrálně rozcházet poté, co do funkce generálního tajemníka SED nastoupil v roce 1971 Erich Honecker. Ten odmítl dodržovat mezinárodní úmluvy a ochranu životního prostředí chápal pouze jako překážku při politickém rozhodování (s. 411-13). V SRN tomu bylo opačně, a to hlavně po prvním ropném šoku v roce 1973, kdy si západoněmecká společnost uvědomila své „limity růstu“. Následujících skoro dvacet let vývoje obou zemí bylo tak rozdílných, že v NDR (a také Československu) došlo k téměř totálnímu zničení Krušných hor. Východoněmecká společnost až do začátku devadesátých let o vymírání lesů většinou ani nevěděla. A nutno přiznat, že se o něj většinou ani nezajímala, pokud zrovna nežila v nejznečištěnější části tohoto pohoří. Přestože tedy v osmdesátých letech vznikaly v NDR první ekologické organizace, jejich činnost se značně lišila od toho, co se dělo v SRN již o deset let dříve. Východoněmecké akce nebyly revolucionářské a až na drobné výjimky si nedovolily hlubší kritiku systému.

Je až s podivem, jak málo se česká věda věnuje problematice environmentální historie. Důsledkem je fakt, že u nás existuje stále jen hrstka projektů, které se životním prostředím zabývají - at již v historii Československa, nebo v rámci vývoje po roce 1990. České environmentální historii by bezpochyby slušelo, kdyby se základy, které Huff položil, staly začátkem větší diskuze o socialistickém přístupu k ochraně životního prostředí.

Pavla Kačmárová

doi: 10.14712/23363231.2017.6

\section{Dušan Drbohlav, ed., Ukrajinská pracovní migrace v Česku. Migrace - remitence - (rozvoj). Praha: Karolinum 2015, 284 s. ISBN 978-80-246-2995-7}

Recenzovaná publikace nazvaná Ukrajinská pracovní migrace v Česku: migrace remitence - (rozvoj) má jasně definovaný předmět výzkumu i geografické zaměření. $\mathrm{V}$ podobě kolektivní monografie vyšla pod vedením předního odborníka na migraci Dušana Drbohlava, který se na katedře sociální geografie a regionálního rozvoje Př́rodovědecké fakulty UK zabývá migračními pohyby a problematikou integrace cizinců do české společnosti. Drbohlav je také vedoucím výzkumného týmu GEOMIGRACE, který se zaměřuje na migranty $z$ bývalého Sovětského svazu a $z$ Vietnamu a jehož členové jsou zároveň spoluautory recenzované knihy. Speciálně ukrajinskými migranty se Drbohlav zabýval již v minulosti, například jako autor studie v ukrajinskojazyčném sborníku nazvaném Mezinárodní migrace a rozvoj Ukrajiny v kontextu evropské integrace. ${ }^{1}$

1 Dušan Drbohlav, „Upravlinnja trudovoju mihracijeju: mriji ta real'nist' (na prykladi Respubliky Čechija)“, in Mižnarodna mihracija ta rozvytok Ukrajiny v konteksti jevropejs'koji intehraciji: $z b$. materialiv mižnar. nauk. konf. (16 žovt. 2007 r., m. Kyjiv), ed. O. A. Malynovs'ka (Kyjiv: Foliant, 2008), 212-25. 